\title{
Monochloro- and dichloroacetic acids as carbon and energy sources for a stable, methanogenic mixed culture
}

\author{
Christine Egli ${ }^{1}$, Markus Thüer ${ }^{2}$, Dieter Suter ${ }^{3}$, Alasdair M. Cook ${ }^{1}$, and Thomas Leisinger ${ }^{1}$ \\ ${ }^{1}$ Microbiology Institute, Swiss Federal Institute of Technology, ETH-Zentrum, CH-8092 Zürich, Switzerland \\ 2 Ciba-Geigy AG, CH-4133 Schweizerhalle, Switzerland \\ ${ }^{3}$ Institute of Quantum Electronics, Swiss Federal Institute of Technology, ETH-Hönggerberg, CH-8093 Zürich, Switzerland
}

\begin{abstract}
A stable methanogenic mixed culture was enriched from an industrial environment to utilize chloroacetate as sole carbon and energy source for growth. It immobilized spontaneously on activated charcoal and grew reproducibly on this carrier in a fluidized bed reactor when supplied with an anaerobic mineral salts medium. Substrate disappearance was complete. Methane, $\mathrm{CO}_{2}$ and chloride ions were conclusively identified as the metabolic products and quantified. The growth yield from chloroacetate was about $1 \mathrm{~g}$ of protein $/ \mathrm{mol}$ of carbon. The calculated degradation rate in the fluidized bed reactor was 0.2 to $0.8 \mathrm{mmol} / 1 \cdot \mathrm{h}$. The first metabolic intermediate from $\left[2-{ }^{13} \mathrm{C}\right]$ monochloroacetate in portions of biofilm-coated carrier was shown by ${ }^{13} \mathrm{C}-\mathrm{NMR}$ to be glycolate, from which ${ }^{13} \mathrm{CO}_{2}$ and ${ }^{13} \mathrm{CH}_{4}$ were formed. Glycolate was formed in an oxygen-insensitive hydrolysis, but its conversion to $\mathrm{CO}_{2}$ and $\mathrm{CH}_{4}$ was strictly anaerobic and sensitive to inhibition by bromoethanesulfonate. Degradation of $\left[1-{ }^{14} \mathrm{C}\right]$ - and $\left[2-{ }^{14} \mathrm{C}\right]$-chloroacetate each yielded the same amount of $\left[{ }^{14} \mathrm{C}\right]$-methane. We thus presume glycolate to be cleaved to $\mathrm{CO}_{2}$ and $\mathrm{H}_{2}$, which were the substrates for methanogenesis. Dehalogenation was limited to chloro-, bromo-, iodo- and dichloroacetate. These four compounds and glycolate were utilized as the sole carbon and energy sources by the methanogenic mixed culture.
\end{abstract}

Key words: Chloroacetates - Haloacetates - Glycolate Anaerobic degradation - Methanogenic mixed culture

The large amounts of chlorinated compounds used in agriculture as insecticides, herbicides, and fungicides give rise to concern (Müller 1988). Environmental problems caused by the bulk chemicals used in their synthesis are less frequently mentioned. Chloroacetic acid is used in molar excess in many syntheses (Koenig 1975), and is classified by the US Environmental Protection Agency as an extremely hazardous chemical (Hanson 1988). Although chloroacetate is readily biodegradable under aerobic conditions, anaerobic degradation could be a useful disposal method.

The degradation of haloalkanoates by aerobic bacteria and fungi has been recognized for some time (Jensen 1959,

Offprint requests to: Th. Leisinger
1963; Goldman 1965), and a considerable understanding of the halidohydrolases involved has been attained (Hardman and Slater 1981; Motosugi and Soda 1983; Müller and Lingens 1986; Tsang et al. 1988). Anaerobic degradation of haloacetates has not been observed, even though monochloroacetate halidohydrolases might be expected to function anaerobically. Further, the product of the dehalogenation reaction, glycolate, is not known to be converted to methane.

We now report the quantitative anaerobic degradation of monochloroacetate and analogues by a stable methanogenic mixed culture.

\section{Materials and methods}

Material. $\quad\left[1-{ }^{14} \mathrm{C}\right]$ Chloroacetic acid $(0.09 \mathrm{TBq} / \mathrm{mol})$, [2$\left.{ }^{14} \mathrm{C}\right]$ chloroacetic acid $(0.30 \mathrm{TBq} / \mathrm{mol})$, and sodium $\left[{ }^{14} \mathrm{C}\right]$ bicarbonate $(0.25 \mathrm{TBq} / \mathrm{mol})$ were obtained from Sigma (St. Louis, MO, USA). $\left[2-^{13}\right.$ C]Chloroacetic acid $(99 \%)$ was obtained from ICN Biomedicals (Cambridge, MA, USA). Scintillation fluid (Ready-Solve HP) was from Beckman (Galway, Ireland). Other chemicals were of the highest quality from Fluka (Buchs, Switzerland) or from MerckSchuchardt (München, FRG). Aromatic pesticides were dissolved in methanol. Activated charcoal (Chemviron Filtrasorb 400; Calgon, Pittsburgh, PA, USA) was the carrier material in the fluidized bed reactor.

Apparatus. Gas chromatography (GC) with flame ionization detection (FID) and thermal conductivity detection (TCD), high pressure liquid chromatography (HPLC) and spectrophotometric analyses were done with standard equipment which was described elsewhere (Egli et al. 1988). GC-mass spectrometry (GC/MS) was done with a Fractorap 2150 GC (Carlo Erba, Rodano, Italy) equipped with a MAT 112 MS (MAT GmbH, Bremen, FRG). The ${ }^{13} \mathrm{C}$ magnetic resonance (NMR) spectra were measured in a commercial spectrometer (AM-400; Bruker, Karlsruhe, FRG) equipped with a $10 \mathrm{~mm}$ broad band probe, tuned to the ${ }^{13} \mathrm{C}$ resonance frequency; the decoupler used a separate Helmholtz coil. The fluidized bed reactor (Fig. 1) was made available by Ciba-Geigy AG (Schweizerhalle, Switzerland). The glovebox (Mercaplex GB 1011) was from Kleiner (Wohlen, Switzerland). 


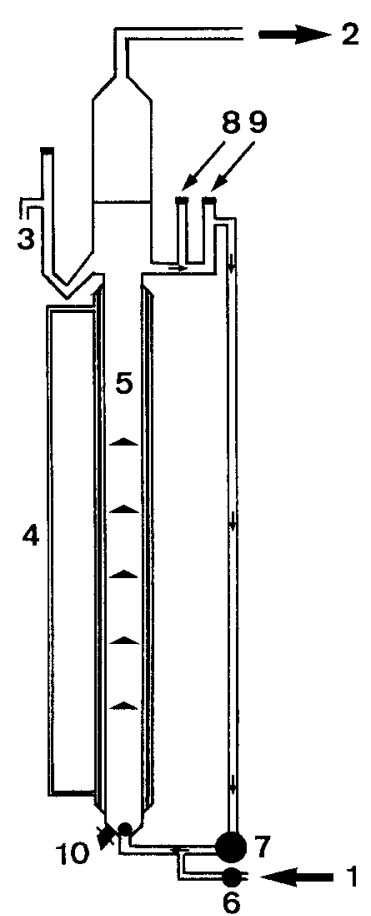

Fig. 1. The anaerobic fluidized bed reactor. Medium and suspended cells were pumped upwards through a water-jacketed vertical cylinder [5] (working volume, 31 ) on which was mounted an expansion head. The liquid passed a $\mathrm{pH}$-stat set at $\mathrm{pH} 7.2$ (inlet for $2 \mathrm{M} \mathrm{NaOH}$ [8]; electrode [9]) and was driven through the system by a pump [7]. The temperature was maintained at $35^{\circ} \mathrm{C}$ by a thermostat [4]. The culture was largely immobilized on activated charcoal (initial packed volume, 0.41 ). Medium with chloroacetate as the sole carbon source was pumped [6] from a 5-1 anaerobic reservoir [ 1$]$ into the system at $21 \mathrm{ml} / \mathrm{h}$. The volume was maintained constant by an overflow [3] and gaseous products vented at [2]. The system had one sampling port [10] from which portions of the fluidized bed could be withdrawn

Analytical methods. Methane was routinely determined (GC/ FID) after separation on a Porapak P column and its identity was confirmed by co-chromatography with authentic material on other columns (Egli et al. 1987) and by GC/MS. Chloroethane and chloroethanol were determined after separation on the same Porapak $\mathrm{P}$ column with the oven temperature set at $130^{\circ} \mathrm{C}$. Acetate was determined after separation on a Porapak Q column (Scholtz et al. 1987) with an oven temperature of $190^{\circ} \mathrm{C}$; identification was confirmed by $\mathrm{GC} / \mathrm{MS} . \mathrm{CO}_{2}$ was determined by $\mathrm{GC} / \mathrm{TCD}$ as described elsewhere (Egli et al. 1988), and its identity was confirmed by $\mathrm{GC} / \mathrm{MS}$. Bicarbonate was assayed as $\mathrm{CO}_{2}$.

All aliphatic substrates and intermediates (chain length $\geq 2$ ) were routinely determined by reversed-phase HPLC (Egli et al. 1988). The mobile phase was amended with 5\% $(\mathrm{v} / \mathrm{v})$ methanol to determine trichloroacetate, 2chloropropionate and 2,2-dichloropropionate. The aromatic substrates 2,4-dichlorophenoxyacetate and 2,4,5trichlorophenoxyacetate were separated on the same column with a mobile phase of potassium phosphate buffer $(10 \mathrm{mM}$, $\mathrm{pH}$ 6.6) containing methanol $[50 \%(\mathrm{v} / \mathrm{v})]$; atrazine was eluted with the same buffer containing more methanol $[75 \%$ (v/v)]. The detector was set at $220 \mathrm{~nm}$ for aromatic compounds.

NMR experiments were done in a static magnetic field of $9.3 \mathrm{~T}$, corresponding to a resonance frequency of
$100 \mathrm{MHz}$ for ${ }^{13} \mathrm{C}$ and $400 \mathrm{MHz}$ decoupler frequency for the protons. Broad band noise decoupling was applied and the decoupler was left on (at a lower power level) during the relaxation time, to achieve nuclear Overhouser enhancement of the ${ }^{13} \mathrm{C}$ signal. The signal: noise ratio was optimized by using a flip angle of $30^{\circ}$ for the excitation pulse and a total time (observation and waiting) between scans of $2.2 \mathrm{~s}$. The measured signals were averaged over $37 \mathrm{~min}$ (1000 scans). Each of those averaged free induction decays was stored on disk and subjected to Fourier-transformation and a digital phase-correction.

Sodium $\left[{ }^{14} \mathrm{C}\right]$ bicarbonate $\left(\right.$ as $\left.\mathrm{CO}_{2}\right)$ was trapped in $1 \mathrm{M}$ $\mathrm{NaOH}$ and radioactivity was measured in portions $(100 \mu \mathrm{l})$ of this solution in liquid scintillation fluid $(5 \mathrm{ml}) .\left[{ }^{14} \mathrm{C}\right]-$ Methane was freed of ${ }^{14} \mathrm{CO}_{2}$ and determined by liquid scintillation counting (Zehnder et al. 1979). Standard material was obtained by biological transformation of $160 \mathrm{TBq}$ $\left[{ }^{14} \mathrm{C}\right]$ sodium bicarbonate to methane by Methanobacterium thermoautotrophicum strain Marburg (DSM 2133) (Balch et al. 1979).

Anaerobic samples, in which chloride ion was to be determined, were mixed with $\mathrm{H}_{2} \mathrm{O}_{2}(30 \% ; 1 \mathrm{ml} / \mathrm{ml}$ sample) in a screw-cap tube, which was capped and heated $\left(80^{\circ} \mathrm{C}, 2 \mathrm{~min}\right)$ to remove traces of $\mathrm{S}^{2-}$ from the liquid phase prior to a colorimetric test (Bergmann and Sanik 1957) or analysis with an ion-specific electrode.

Protein in whole cells was measured by a Lowry method (Cook and Hütter 1981).

Organisms grown on particles of activated charcoal were prepared for scanning electron microscopy by washing in water and fixing for $2 \mathrm{~h}$ with $3 \%$ glutaraldehyde in $0.1 \mathrm{M}$ sodium cacodylate buffer, $\mathrm{pH} 7.4$, washing with water, and postfixing for $1 \mathrm{~h}$ with $1 \%$ osmium tetroxide in buffer. Samples were washed twice in water, dehydrated with dimethoxypropane (Muller and Jacks 1975), and washed twice with acetone. Thereafter, they were subjected to critical point drying (Anderson 1951). Dried samples were sputtercoated with a $70 \mathrm{~nm}$ layer of gold/palladium according to the manufacturer's instructions.

Inoculum, growth media and growth conditions. The inoculum for the enrichment cultures was a mixture of two activated sludges from communal and industrial waste treatment plants, and of anaerobically digested sludge from the communal plant. Enrichment cultures (made to 11 with tap water in 1.2-1 glass bottles) contained inoculum $(10 \mathrm{ml})$, and three different amounts of a neutralized chemical waste such that 1 to $10 \mathrm{mM}$ chloroacetate (and 0.1 to $1 \mathrm{mM}$ dichloroacetate) was the major carbon and energy source. Controls contained inoculum and water. The bottles were sparged with nitrogen, sealed with butyl rubber stoppers and incubated under nitrogen with gentle shaking at $35^{\circ} \mathrm{C}$. Gas production was measured at intervals.

The enrichment culture which degraded chloroacetate was used as inoculum for a fluidized bed reactor in which organisms immobilized spontaneously on the charcoal carrier (Fig. 1). The mineral medium used in this reactor was prepared by boiling $(30 \mathrm{~min}) 15 \mathrm{mM} \mathrm{KK_{2 }} \mathrm{PO}_{4}, 10 \mathrm{mM}$ $\mathrm{NH}_{4} \mathrm{Cl}, 0.7 \mathrm{mM} \mathrm{CaCl}, 0.5 \mathrm{mM} \mathrm{MgCl}_{2}$, and $10 \mathrm{ml} / 1$ of a trace elements solution (Schönheit et al. 1979) under a stream of $\mathrm{N}_{2}$ plus $\mathrm{CO}_{2}[80: 20(\mathrm{v} / \mathrm{v})]$. After cooling, $1 \mathrm{ml} / 1$ of a filter-sterilized vitamin solution (Schönheit et al. 1979), solid chloroacetic acid ( 3 to $110 \mathrm{mM}$ ) and solid cysteine$\mathrm{HCl}$ (final concentration $0.3 \mathrm{mM}$ ) were added. Medium for 


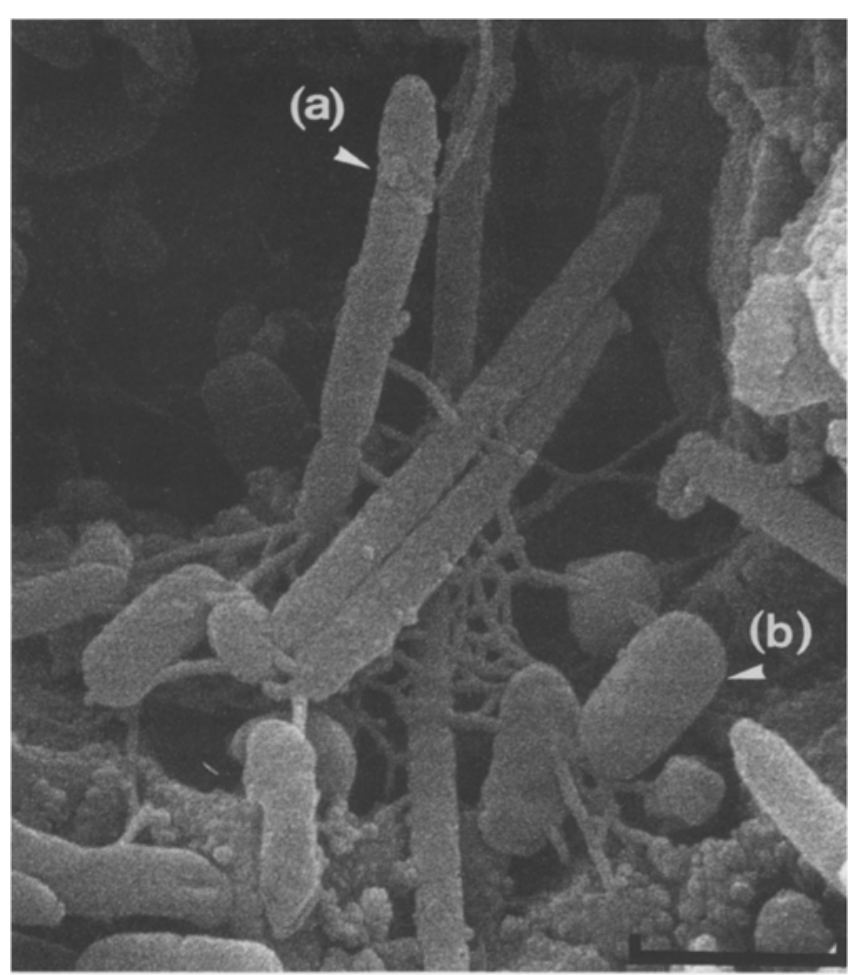

Fig. 2. Electron micrograph of the methanogenic mixed culture immobilized on charcoal. Two predominant, morphologically different bacteria were observed: $(a)$ a long rod $(3 \times 0.3 \mu \mathrm{m})$, presumed to be a methanogen because of its F420 autofluorescence and $(b)$ a short $(0.9 \times 0.6 \mu \mathrm{m})$, non-methanogenic organism. The bar represents $1 \mu \mathrm{m}$

continuous operation of the reactor was stored in a reservoir (51) which was closed with a rubber stopper and connected to the feed pump by air-tight connections.

Degradation of $\left[2-{ }^{13} \mathrm{C}\right]$ chloroacetate by the immobilized mixed culture. Experiments were done at $34^{\circ} \mathrm{C}$ in a $1-\mathrm{cm}$ diameter NMR-tube. Additions to the tube were made under a stream of nitrogen and the tube was sealed with a rubber stopper. Biofilm-coated charcoal particles were washed inside the anaerobic chamber with anaerobic buffer, $\mathrm{pH} 7.2$ $\left[60 \mathrm{mM} \mathrm{NaHCO} 3,1.7 \mathrm{mM} \mathrm{KH} \mathrm{KHO}_{4}, 1 \mathrm{ml} / \mathrm{l}\right.$ titanium(III) citrate (Zehnder and Wuhrmann 1976) and $0.1 \mathrm{ml}$ resazurin solution $(1 \mathrm{mg} / \mathrm{l})]$. Reaction mixtures $(4 \mathrm{ml})$ contained washed particles $(0.3 \mathrm{ml}$ packed volume), anaerobic buffer and $\left[2-{ }^{13} \mathrm{C}\right]$ chloroacetic acid $(36 \mu \mathrm{mol})$. A similar experiment was done under aerobic conditions with $12 \mu \mathrm{mol}$ of $\left[2{ }^{13} \mathrm{C}\right]$ chloroacetic acid. The sample was shaken by hand at $2 \mathrm{~h}$ intervals to maintain homogeneous conditions. Soluble compounds were analyzed by NMR. The gas phase was examined by GC and GC/MS.

Degradation of $\left[{ }^{14} C\right]$ chloroacetate. The immobilized mixed culture was used to follow the fate of carbon atoms from [1$\left.{ }^{14} \mathrm{C}\right]$ - or $\left[2-{ }^{14} \mathrm{C}\right] \mathrm{chloroacetic}$ acid in $16.5 \mathrm{ml}$ Hungate tubes. Washed, biofilm-coated carrier ( $3 \mathrm{ml}$ packed volume) was added to the tube and the gas phase was replaced with $\mathrm{N}_{2}$ plus $\mathrm{CO}_{2}[80: 20(\mathrm{v} / \mathrm{v}), 0.2$ bar] using a gassing manifold (Kiener and Leisinger 1983). Anaerobic buffer $(5 \mathrm{ml})$ and $\left[1-{ }^{14} \mathrm{C}\right]$ chloroacetic acid $(0.58 \mu \mathrm{mol}, 51 \mathrm{kBq})$ or $\left[2-{ }^{14} \mathrm{C}\right] \mathrm{chlo}-$ roacetic acid $(0.25 \mu \mathrm{mol}, 76 \mathrm{kBq})$ were added to the test.
After a two-day incubation period, the reaction was stopped by adding $5 \mathrm{M} \mathrm{NaHO}(400 \mu \mathrm{l})$. The tube was stirred overnight to trap $\mathrm{CO}_{2}$ in the aqueous phase. Methane in the headspace $(0.2 \mathrm{ml})$ was analyzed for radioactivity (Zehnder et al. 1979). The liquid phase was transferred to one side of a two-armed vessel (Fuchs et al. 1980), acidified (500 $\mu$ of concentrated $\mathrm{H}_{2} \mathrm{SO}_{4}$ ) to drive off $\mathrm{CO}_{2}$, which was trapped in $1 \mathrm{M} \mathrm{NaOH}(2 \mathrm{ml})$ in the second arm and quantified by liquid scintillation counting.

Substrate range of the immobilized methanogenic mixed culture and inhibition studies. Biofilm-coated charcoal particles in the anaerobic chamber were washed twice with anaerobic buffer and transferred to sterile $16.5-\mathrm{ml}$ Hungate tubes to give a packed volume of $2 \mathrm{ml}$. The gas phase in the tubes was replaced with $\mathrm{N}_{2}$ plus $\mathrm{CO}_{2}[80: 20(\mathrm{v} / \mathrm{v}), 0.2$ bar]. Sterile anaerobic buffer $(5 \mathrm{ml})$ and substrate (initial concentration for aliphatics $3 \mathrm{mM}$, for aromatics $0.3 \mathrm{mM}$ ) were added. In selected experiments, methanogenic organisms were inhibited with sodium bromoethanesulfonate $(50 \mathrm{mM})$. Substrates [HPLC, except chloroethane and chloroethanol (GC)], chloride (colorimetry or electrode), and methane (GC) were determined in duplicate at 0 and $48 \mathrm{~h}$ of incubation.

\section{Results}

\section{Enrichment cultures and growth medium}

Experiments to obtain methanogenic enrichment cultures in chloroacetate-salts medium indicated that this substrate was toxic for anaerobic bacteria present in the inoculum. Whereas controls without chloroacetate produced methane from endogenous carbon sources within $24 \mathrm{~h}, 1 \mathrm{mM}$ chloroacetate caused a one-week delay in methanogenesis and $10 \mathrm{mM}$ substrate caused complete inhibition. One positive enrichment was obtained, at $4 \mathrm{mM}$ chloroacetate; after 7 weeks of incubation its methane production was tenfold increased as compared to the control.

The culture grew irreproducibly in the enrichment medium. Stable conditions were obtained in a fluidized bed reactor. Immobilisation of organisms on the carrier (activated charcoal) was spontaneous. Formulation of anaerobic chloroacetate-minimal medium required care, because chloroacetate is a reactive compound subject to spontaneous nucleophilic attack by thiol groups (Dickens 1933). Thioglycolate accumulated in large amounts in many media, due to the presence or microbial formation of sulfide, and methanogenesis was inhibited. This artefact was avoided by using only trace amounts of sulfur $(0.3 \mathrm{mM}$ cysteine- $\mathrm{HCl})$ and/or titanium(III) citrate to generate reducing conditions.

\section{Degradation of chloroacetate in a fluidized bed reactor}

Growth in the reactor was initiated as a batch culture with $3 \mathrm{mM}$ chloroacetate. When the substrate had disappeared and methane production was observed, a continuous feed was started with a weekly increase in the chloroacetate concentration of the medium in the reservoir. The chloroacetate concentration in the culture was below $0.2 \mathrm{mM}$ when e.g., $30 \mathrm{mM}$ substrate was in the feed; the observed products were methane, $\mathrm{CO}_{2}$, chloride and traces $(<0.5$ to $2 \mathrm{mM})$ of acetate and glycolate. 


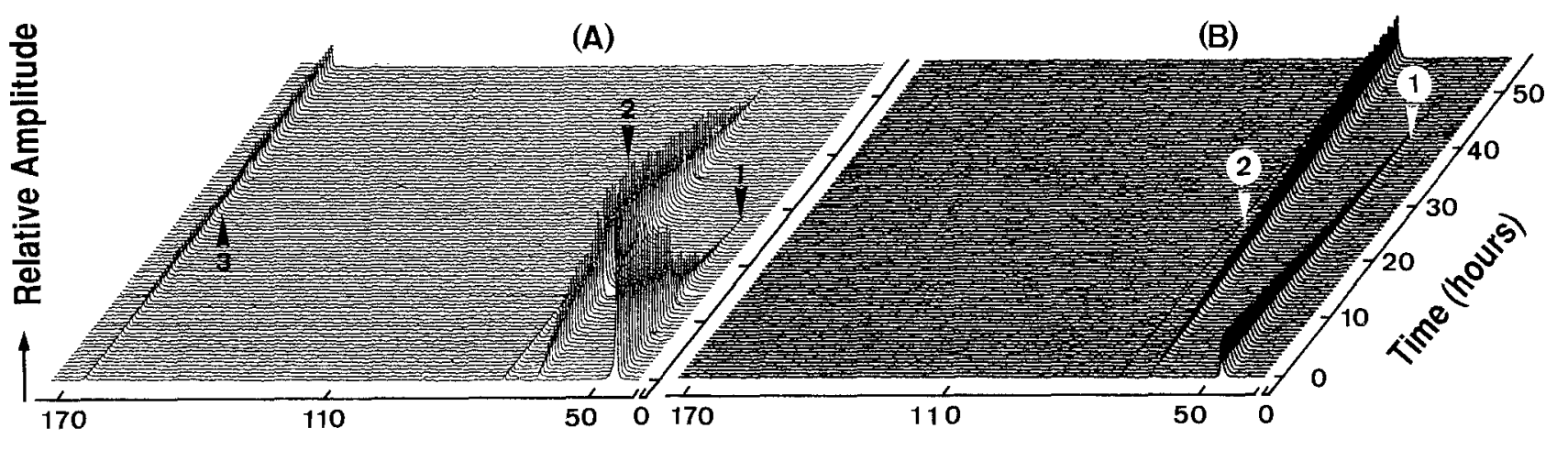

\section{Chemical shift (ppm from TMS)}

Fig. 3A, B. Kinetics of the transformation of $\left[2-{ }^{13} \mathrm{C}\right]$ chloroacetate to products by the methanogenic mixed culture immobilized on charcoal. The vessel containing the biological reaction mixture was mounted in a ${ }^{13} \mathrm{C}-\mathrm{NMR}$ spectrometer and spectra were taken at intervals and plotted as pseudo-3-dimensional graphs. The chemical shifts ( $\mathrm{ppm}$ ) of standards (the ${ }^{13} \mathrm{C}$-component of authentic materials) measured under identical conditions, which agreed with literature data (Pretsch et al. 1976), identified the signals as $\left[2-{ }^{13} \mathrm{C}\right] \mathrm{chloroacetate}[48.8$ ppm; marked $l$ in $(\mathbf{A})+(\mathbf{B})],\left[2-{ }^{13}\right.$ C]glycolate $[67.4 \mathrm{ppm}$; marked 2 in $(\mathbf{A})+(\mathbf{B})]$ and ${ }^{13} \mathrm{CO}_{3}^{2-}[168.3$ ppm; marked 3 in (A)]. Two representative experiments are shown: (A), under strictly anaerobic conditions ( $9 \mathrm{mM}$ chloroacetate); $(\mathbf{B})$ under aerobic conditions ( $3 \mathrm{mM}$ chloroacetate)

Table 1. Degradation of $\left[1-{ }^{14} \mathrm{C}\right]-$ and $\left[2-{ }^{14} \mathrm{C}\right]$ chloroacetate by the methanogenic mixed culture

\begin{tabular}{lllll}
\hline \multirow{2}{*}{ Compound added } & \multicolumn{4}{c}{ Radioactivity (\%) recovered in } \\
\cline { 2 - 5 } & $\mathrm{CH}_{4}$ & $\mathrm{CO}_{2}$ & Biomass & Total $^{\mathrm{a}}$ \\
\hline$\left[2^{14} \mathrm{C}\right]$ Chloroacetate & 11 & 60 & 15 & 86 \\
{$\left[1-^{14} \mathrm{C}\right]$ Chloroacetate } & 12 & 74 & 4 & 90 \\
\hline
\end{tabular}

${ }^{\text {a }}$ Data represent the average of two experiments

The degradation rate for chloroacetate after six months in the fluidized bed system was $0.2 \mathrm{mmol} / 1 \cdot \mathrm{h}$, and the mass balance was:

$$
\begin{array}{rl}
30 & \mathrm{mM} \mathrm{ClCH} \\
& \mathrm{COOH} \\
& \rightarrow 23 \mathrm{mM} \mathrm{CH}_{4}+33 \mathrm{mM} \mathrm{H}_{2} \mathrm{CO}_{3}+30 \mathrm{mM} \mathrm{HCl} \\
& +2.3 \mathrm{mM} \text { carbon in protein. }
\end{array}
$$

This corresponds to $97 \%$ and $100 \%$ recovery of carbon and chloride, respectively. The amount of protein produced $(1 \mathrm{~g}$ of protein/mol of C) is typical for anaerobic growth (Dolfing and Tiedje 1987). Chloroacetate was thus subject to total degradation by the methanogenic mixed culture.

The concentration of chloroacetate in the feed was increased to $110 \mathrm{mM}$. There was no detectable chloroacetate in the culture medium, and the degradation rate was calculated to be $0.76 \mathrm{mmol} / 1 \cdot \mathrm{h}$. The feed concentration was not increased above $110 \mathrm{mM}$ to avoid excessive concentrations of sodium chloride and sodium carbonate in the reactor.

The organisms on the carrier are shown in Fig. 2. Cells tended to colonize niches in the charcoal rather than the outer surface of the carrier. Examination of samples by fluorescence microscopy indicated that methanogens and non-methanogens were present.

\section{Glycolate and $\mathrm{HCO}_{3}^{-}$as intermediates}

The degradation of chloroacetate by the immobilized mixed culture was followed in situ by non-invasive ${ }^{13} \mathrm{C}-\mathrm{NMR}$ analyses. Under anaerobic conditions, chloroacetate ( $36 \mu \mathrm{mol}$ ) was converted within $22 \mathrm{~h}$ to glycolate, the sole measurable organic intermediate, which was in turn degraded to carbonate (Fig. $3 \mathrm{~A}$ ). Headspace analyses showed that $24 \mu \mathrm{mol}$ of methane was produced and that both $\left[{ }^{12} \mathrm{C}\right]-$ and $\left[{ }^{13} \mathrm{C}\right]$ methane was formed. The relative amounts of $\left[{ }^{14} \mathrm{C}\right]$ methane formed from $\left[1-{ }^{14} \mathrm{C}\right]-$ or $\left[2-{ }^{14} \mathrm{C}\right]$ chloroacetate were identical (Table 1). These tracer experiments clearly indicate that both the C-1 and C-2 carbon of chloroacetate gave rise to methane with equal efficiency. Glycolate was presumably cleaved to $2 \mathrm{~mol}$ of $\mathrm{CO}_{2}$, and this $\mathrm{CO}_{2}$ was the major carbon source for methanogenesis in the system. Chloroacetate was subject to hydrolysis to glycolate under aerobic conditions also, but at a lower rate; this glycolate was not degraded aerobically (Fig. 3B). It seems that hydrolytic dehalogenation is less oxygen-sensitive than glycolate degradation.

\section{Substrate range and inhibition of the immobilized culture}

Several chlorinated compounds were tested as substrates for dechlorination and degradation by the immobilized mixed culture. 2-Chloropropionate, 2,2-dichloropropionate, chloroethane, 2-chloroethanol, atrazine, 2,4-dichlorophenoxyacetate, and 2,4,5-trichlorophenoxyacetate were neither dechlorinated nor degraded. Mono-, di-, and trichloroacetate were totally dechlorinated and degraded to methane and $\mathrm{CO}_{2}$ (Table 2). Trichloroacetate degradation was a combination of chemical and biological reactions (Table 2). Bromoacetate and iodoacetate were totally degraded, but fluoroacetate was not a substrate. Whereas glycolate was utilized by the mixed culture, acetate was not (Table 2).

Concentrations of bromoethanesulfonate above $20 \mathrm{mM}$ were required to obtain any inhibition of methane production by the charcoal-immobilized mixed culture. At a concentration of $50 \mathrm{mM}$ bromoethanesulfonate, methane production was totally inhibited. Dehalogenation of chloroacetate was not affected by the presence of bromoethanesulfonate, whereas glycolate degradation was partially inhibited (Table 2). Acetate was produced under these conditions, presumably by acetogenic bacteria present in the system. 
Table 2

Substrate range of the stable, immobilized methanogenic mixed culture

${ }^{a}$ All substrates were stable, except trichloroacetate $\left({ }^{c}\right)$, and were present at an initial concentration of $3 \mathrm{mM}$. The limits of detectability are given in Materials and methods ${ }^{\mathrm{b}}$ Product formation was measured after 2 days of incubation. Experiments were done twice, with similar results, and these data are the means of duplicate assays

c Trichloroacetate, though stable under sterile, charcoalfree conditions, reacted spontaneously to form dichloroacetate in the presence of sterile charcoal. Trichloroacetate degradation was thus a combination of chemical and biological reactions

${ }^{\text {d na, no assay }}$

e BES, bromoethanesulfonate

\begin{tabular}{lllll}
\hline $\begin{array}{l}\text { Substrate added } \\
(15 \mu \mathrm{mol})\end{array}$ & $\begin{array}{l}\text { Residual } \\
\text { substrate } \\
(\mu \mathrm{mol})\end{array}$ & \multicolumn{3}{l}{ Products formed ${ }^{\mathrm{b}}(\mu \mathrm{mol})$} \\
\cline { 3 - 5 } & - & 0.3 & 0.2 & 0 \\
\hline None & 0 & 9.4 & 15 & 0 \\
$\mathrm{ClCH}_{2} \mathrm{COO}^{-}$ & 0 & 7.4 & 29 & 0 \\
$\mathrm{Cl}_{2} \mathrm{CHCOO}^{-}$ & 0 & 6.8 & 44 & 0 \\
$\mathrm{Cl}_{3} \mathrm{COO}^{-}$ & 0 & 9.4 & - & 0 \\
$\mathrm{CH}_{2} \mathrm{HOCOO}^{-}$ & 0 & 9.3 & 15 & 0 \\
$\mathrm{BrCH}_{2} \mathrm{COO}^{-}$ & 0 & 3.1 & 14 & 0 \\
$\mathrm{ICH}_{2} \mathrm{COO}^{-}$ & 0 & 0.4 & nalide & 0 \\
$\mathrm{FCH}_{2} \mathrm{COO}^{-}$ & 15 & 0.3 & - & 0 \\
$\mathrm{CH}_{3} \mathrm{COO}^{-}$ & 15 & 0.1 & 15 & $\mathrm{CH}_{3} \mathrm{COO}^{-}, 4$ \\
$\mathrm{ClCH}_{2} \mathrm{COO}^{-}$ & 0 & & & $\mathrm{CH}_{2} \mathrm{HOCOO}^{-}, 6$ \\
$+50 \mathrm{mM} \mathrm{BES}^{\mathrm{e}}$ & & & & $\mathrm{CH}_{3} \mathrm{COO}^{-}, 5$ \\
$\mathrm{CH}_{2} \mathrm{HOCOO}^{-}$ & 6 & 0.2 & - & \\
$+50 \mathrm{mM} \mathrm{BES}^{+}$ & & & & \\
\hline
\end{tabular}

\section{Discussion}

The methanogenic, chloroacetate-utilizing mixed culture was maintained as a continuous culture immobilized on activated charcoal in a fluidized bed reactor. This method of cultivation allowed the use of non-reduced medium, a critical precaution which avoided a chemical reaction between chloroacetate and sulfide. Immobilization may have favoured the degradation process since it allowed juxtaposition of the hydrogen-producing and the methanogenic partners of the system (Conrad et al. 1985). Strictly anaerobic conditions must have existed in the pockets of the charcoal carriers, in which methanogens were observed, whereas a gradient of anaerobiosis from a relatively high redox potential at the inlet for the non-reduced medium must be postulated for the bioreactor as a whole.

Chloroacetate degradation by the methanogenic mixed culture described here proceeded to completion according to the following overall stoichiometry:

$$
\begin{aligned}
& 4 \mathrm{ClCH}_{2} \mathrm{COO}^{-}+7 \mathrm{H}_{2} \mathrm{O} \\
& \quad \rightarrow 5 \mathrm{HCO}_{3}^{-}+3 \mathrm{CH}_{4}+4 \mathrm{Cl}^{-}+5 \mathrm{H}^{+}
\end{aligned}
$$

At least two pathways are conceivable by which chloroacetate could be converted to methane, $\mathrm{CO}_{2}$ and chloride. Firstly a fermentative bacterium could anaerobically oxidize part of the chloroacetate, dispose of electrons by reductively dehalogenating the major part of chloroacetate and thereby provide acetate for an aceticlastic methanogen. Secondly chloroacetate could be hydrolytically dehalogenated to glycolate which could be cleaved to yield carbon dioxide and hydrogen, the substrates of a carboxidotrophic methanogen.

Our data suggest strongly that anaerobic chloroacetate degradation proceeds by the latter pathway. Evidence for this rests on the identification of glycolate as an intermediate (Fig. 3), on the oxidation of both the C-1 and the C-2 carbons of chloroacetate to $\mathrm{CO}_{2}$, on the equivalence of both carbon atoms to act as precursors of methane (Table 1), and on the fact that acetate was not utilized as a substrate by the methanogenic mixed culture (Table 2). Similar molar yields of methane were observed with glycolate, chloroacetate and bromoacetate. When dichloroacetate was supplied as a substrate, the yield of methane decreased significantly. This is in agreement with the fact that dichloroacetate is more oxidized than monochloroacetate and that its anaerobic oxidation yields correspondingly less hydrogen.
The data presented here suggest that at last two metabolic types bacteria are involved in the anaerobic degradation of chloroacetate via the reactions shown in Eq. (1), (2) and (3).

$$
\begin{aligned}
& 4 \mathrm{ClCH}_{2} \mathrm{COO}^{-}+4 \mathrm{H}_{2} \mathrm{O} \\
& \rightarrow 4 \mathrm{CH}_{2} \mathrm{OHCOO}^{-}+4 \mathrm{Cl}^{-}+4 \mathrm{H}^{+} \\
& 4 \mathrm{CH}_{2} \mathrm{OHCOO}^{-}+12 \mathrm{H}_{2} \mathrm{O} \rightarrow 8 \mathrm{HCO}_{3}^{-}+12 \mathrm{H}_{2}+4 \mathrm{H}^{+} \\
& \Delta G_{(2)^{\prime}}^{\mathrm{o}}=28.8 \mathrm{~kJ} / \mathrm{mol}^{\prime} \\
& 12 \mathrm{H}_{2}+3 \mathrm{HCO}_{3}^{-}+3 \mathrm{H}^{+} \rightarrow 3 \mathrm{CH}_{4}+9 \mathrm{H}_{2} \mathrm{O} \\
& \Delta G_{(3)^{\prime}}^{\circ}=-135.3 \mathrm{~kJ} / \mathrm{mol} \\
& \Delta G_{(3)^{\prime}}^{\mathrm{o}}+\Delta \mathrm{G}_{(2)^{\prime}}^{\circ}=-106.5 \mathrm{~kJ} / \mathrm{mol}
\end{aligned}
$$

Values for the free energy of formation $\left[\Delta G^{\mathrm{o}}\right]$ were calculated from $\Delta G_{\mathrm{f}}^{\circ}$ values at $25^{\circ} \mathrm{C}$ (Thauer et al. 1977).

The initial degradative step [Eq. (1)] is hydrolytic, with glycolate plus chloride as the products. This exergonic reaction is well known in aerobic chemoheterotrophic soil bacteria of the genera Pseudomonas and Moraxella in which it is mediated by inducible halidohydrolases (Müller and Lingens 1986). The narrow substrate specificity of the dehalogenating mixed culture described here suggests a haloacetate halidohydrolase of the type that does not cleave the C-F bond (Motosugi and Soda 1983). Whereas it seems likely that this halidohydrolase is present in the fermentative bacterium postulated to degrade glycolate [Eq. (2)], we cannot exclude that the enzyme is furnished by an anaerobic organism growing on excretion and/or lysis products present in the system.

Glycolate is a novel substrate for a methanogenic mixed culture. Anaerobic oxidations of alkanoic acids by syntrophic associations of bacteria are well documented (McInerney et al. 1979; Zinder and Koch 1984; Stieb and Schink 1985; Platen and Schink 1987; Lee and Zinder 1988), but to our knowlegde there are no reports of the anaerobic oxidation of hydroxyalkanoic acids such as glycolate. In view of the unfavourable thermodynamics of glycolate fermentation to carbon dioxide and hydrogen [Eq. (2)] one has to postulate that this part of chloroacetate degradation can proceed only when the hydrogen partial pressure in the system is kept low by syntrophic association of the glycolate degrader with a hydrogen-consuming organism. In this chloroacetate-(glycolate-)degrading mixed culture the hydrogen-scavenging partner appears to be a methanogen 
that obtains energy from growth by the reduction of carbon dioxide with hydrogen [Eq. (3)]. Evidence for the presence of this type of organism in the system was provided by the detection of fluorescing bacteria in the pockets of the charcoal-carrier and by inhibition experiments. Methanogenesis from chloroacetate or glycolate was completely and glycolate degradation was strongly inhibited by bromoethanesulfonate (Table 2).

Acknowledgements. We are grateful to U. Schefer for GC/MS analyses. Some of the experiments were performed at the Lawrence Berkeley Laboratory, Berkeley, California. We thank Prof. A. Pines for generously providing the spectrometer time. This work was supported by a grant from the Swiss Federal Institute of Technology, Zürich.

\section{References}

Anderson TF (1951) Techniques for the preservation of three dimensional structure in preparing specimens for the electron microscope. Trans N Y Acad Sci 13:130-134

Balch WE, Fox GE, Magrum LJ, Woese CR, Wolfe RS (1979) Methanogens: reevaluation of a unique biological group. Microbiol Rev 43:260-296

Bergmann JG, Sanik J (1957) Determination of trace amounts of chlorine in naphtha. Anal Chem 29:241-243

Conrad R, Phelps TJ, Zeikus JG (1985) Gas metabolism evidence in support of the juxtaposition of hydrogen-producing and methanogenic bacteria in sewage sludge and lake sediments. Appl Environ Microbiol 50:595-601

Cook AM, Hütter R (1981) s-Triazines as nitrogen sources for bacteria. J Agric Food Chem 29:1135-1143

Dickens $F$ (1933) Interaction of halogenacetates and SH compounds. The reaction of halogenacetic acids with glutathione and cysteine. The mechanism of iodoacetate poisoning of glyoxalase. Biochem J 27:1141 - 1151

Dolfing J, Tiedje JM (1987) Growth yield increase linked to reductive dechlorination in a defined 3-chlorobenzoate degrading methanogenic coculture. Arch Microbiol 149:102 - 195

Egli C, Scholtz R, Cook AM, Leisinger T (1987) Anaerobic dechlorination of tetrachloromethane and 1,2-dichloroethane to degradable products by pure cultures of Desulfobacterium sp. and Methanobacterium sp. FEMS Microbiol Lett 43:257261

Egli C, Tschan T, Scholtz R, Cook AM, Leisinger T (1988) Transformation of tetrachloromethane to dichloromethane and carbon dioxide by Acetobacterium woodii. Appl Environ Microbiol $54: 2819-2824$

Fuchs G, Stupperich E, Eden G (1980) Autotrophic $\mathrm{CO}_{2}$ fixation in Chlorobium limicola. Evidence for the operation of a reductive tricarboxylic acid cycle in growing cells. Arch Microbiol 128: $64-71$

Goldman P (1965) The enzymatic cleavage of the carbon-fluorine bond in fluoroacetate. J Biol Chem 240:3434-3438

Hanson D (1988) Chemical emergency handling study cites needs. Chem Eng News 66(26): 24

Hardman DJ, Slater JH (1981) Dehalogenases in soil bacteria. J Gen Microbiol 123:117-128

Jensen HL (1959) Decomposition of chlorine-substituted organic acids by fungi. Acta Agric Scand 9:421 - 434
Jensen HL (1963) Carbon nutrition of some microorganisms decomposing halogen-substituted aliphatic acids. Acta Agric Scand 13:404-412

Kiener A, Leisinger T (1983) Oxygen sensitivity of methanogenic bacteria. Syst Appl Microbiol 4:305-312

Koenig G (1975) Chloressigsäuren. In: Bartholomé E, Biekert E, Hellmann H, Lry H, Weigert WM (ed) Ullmanns Enzyklopädie der Technischen Chemie, 4th edn, vol 9. Verlag Chemie, Weinheim, pp 393-403

Lee MJ, Zinder SH (1988) Isolation and characterization of a thermophilic bacterium which oxidizes acetate in syntrophic association with a methanogen and which grows acetogenically on $\mathrm{H}_{2}-\mathrm{CO}_{2}$. Appl Environ Microbiol 54:124-129

McInerney MJ, Bryant MP, Pfennig N (1979) Anaerobic bacterium that degrades fatty acids in syntrophic association with methanogens. Arch Microbiol 122:129-135

Motosugi K, Soda K (1983) Microbial degradation of synthetic organochlorine compounds. Experientia 39:1214 - 1220

Müller P (1988) Effects of pesticides on fauna and flora. In: Pesticides: food and environmental implications. Proceedings of a symposium, Neuherberg, 24-27 November 1987, organized by IAEA and FAO. International Atomic Energy Agency, Vienna, pp $11-27$

Müller R, Lingens F (1986) Mikrobieller Abbau halogenierter Kohlenwasserstoffe: Ein Beitrag zur Lösung vieler Umweltprobleme? Angew Chem 98:778 - 787

Muller LL, Jacks TJ (1975) Rapid chemical dehydration of samples for electron microscopic examinations. J Histochem Cytochem $23: 107-110$

Platen H, Schink B (1987) Methanogenic degradation of acetone by an enrichment culture. Arch Microbiol 149:136-141

Pretsch E, Clerc T, Seibl J, Simon W (1976) Tabellen zur Strukturaufklärung organischer Verbindungen mit spektroskopischen Methoden. Springer, Berlin Heidelberg New York

Schönheit P, Moll J, Thauer RK (1979) Nickel, cobalt, and molybdenum requirement for growth of Methanobacterium thermoautotrophicum. Arch Microbiol 123:105-107

Scholtz R, Schmuckle A, Cook AM, Leisinger T (1987) Degradation of eighteen 1-monohaloalkanes by Arthrobacter sp. strain HA1. J Gen Microbiol 133:267-274

Stieb M, Schink B (1985) Anaerobic oxidation of fatty acids by Clostridium bryantii sp. nov., a sporeforming obligately syntrophic bacterium. Arch Microbiol 140:387-390

Thauer RK, Jungermann K, Decker K (1977) Energy conservation in chemotropic anaerobic bacteria. Bacteriol Rev $41: 100-180$

Tsang JSH, Sallis PJ, Bull AT, Hardman DJ (1988) A monobromoacetate dehalogenase from Pseudomonas cepacia MBA4. Arch Microbiol 150:441 - 446

Zehnder AJB, Wuhrmann K (1976) Titanium(III) citrate as a nontoxic oxidation-reduction buffering system for the culture of obligate anaerobes. Science 194:1165-1166

Zehnder AJB, Huser B, Brock TD (1979) Measuring radioactive methane with the liquid scintillation counter. Appl Environ Microbiol 37:897-899

Zinder SH, Koch M (1984) Non-aceticlastic methanogenesis from acetate: acetate oxidation by a thermophilic syntrophic coculture. Arch Microbiol 138:263-272 